\title{
A Works Council's Response to Decent Work Deficits Facing Agricultural Employees in Zimbabwe
}

\section{Moment Bhebhe and Prince Takaindisa}

Department of Human Resource Management, Midlands State University Main Campus, Zimbabwe

*Corresponding author: mbhebhe@staff.msu.ac.zw

Received: 13-09-2020

Revised: $21-11-2020$

Accepted: 04-12-2020

\begin{abstract}
This study examined the role and challenges faced by the works council in addressing decent work deficits within the agricultural industry in Zimbabwe. The pervasiveness of decent work deficits in organisations within the agricultural industry in the global economy, including in Zimbabwe, remains of major concern. To address this, the research took a qualitative case-study approach in a selected Agribusiness in Zimbabwe. The study involved 18 purposively selected participants, all who are members of the works council (management and workers' committee), including experts from the human resource and industrial relations department in the organisation. Nine semi-structured interviews were conducted with the management participants and a focus group discussion was held with all the workers' committee members. The major study findings revealed the presence of decent work deficits in the organisation. The works council members confirmed that the agrarian employees in the organisation face indecent work conditions characterised by insufficient wages, long hours of work, a lack of adequate personal protective clothing and insecurities attached to temporary employment. In addressing these deficits, the works council was found to be incapacitated due in part, to: failure to regularly hold meetings; constant use of threats by management against members of the workers' committee; and inadequate knowledge and skills particularly on the part of the workers' committee. It is recommended that the human resources and industrial relations department plays a more active role to ensure the effective functioning of the works council.
\end{abstract}

Keywords: decent work deficits, works council, social dialogue, agricultural industry

Globally, the world of work has increasingly become less stable, resulting in the deterioration on the quality of work for the employed. The $21^{\text {st }}$ century has presented numerous challenges for many organisations, with profound effects on employment relations and human resource management (Hyman and GumbrellMcCormick, 2017). Within the world of work, decent work deficits remain widespread in many parts of the world and addressing these remains focal (ILO, 2018; LeBaron, 2018). Decent work deficits relate to deficiencies in the quality and outcomes of work for those in paid jobs (World Employment and Social Outlook, 2020). Employment conditions are regarded as deficient when they are associated with insufficient wages, poor social protection, inadequate exercise of employee rights and failure to guarantee security of employment (Karatepe and Scherrer, 2019).

The agriculture industry remains the largest employer in the world (Sinaga, 2018), employing about a third of the global workforce (Karatepe and Scherrer, 2019). It is generally regarded to be a labour-intensive industry

How to cite this article: Bhebhe, M. and Takaindisa, P. (2020). A Works Council's Response to Decent Work Deficits Facing Agricultural Employees in Zimbabwe. Int. J. Soc. Sci., 9(04): 219-227.

Source of Support: None; Conflict of Interest: None 
(Scherrer, 2019). In many parts of the world, particularly in the African continent, agriculture contributes significantly to enhanced national productivity and food security as seen by Akorsu and Britwum (2018). In Zimbabwe, the agriculture industry remains the mainstay of the economy and is envisioned to help produce sustainable growth prospects for the nation (Sibanda, 2019; IMF, 2019). About 70\% of Zimbabwe's approximately 13 million people rely on agricultural produce for livelihood (Zimstat, 2019). Nonetheless, decent work deficits within the agriculture industry in Zimbabwe and beyond, remain widespread (LeBaron, 2018; Verma, 2018; Sibanda, 2019; Dedeoglu and Bayraktar, 2019; World Employment and Social Outlook, 2020).

The pervasiveness of decent work deficits in Zimbabwe's agricultural industry is a key issue, with work conditions found to be exploitative, precarious and abusive. Wage poverty remains of major concern in this industry (Chakanya, 2016; Chambati, 2017). Rampant underpayment of wages, labour casualisation and child labour are reportedly high in Zimbabwe's prime industry (Mukwakwami and Uzhenyu, 2017), with most employees lacking access to pay slips and suffering from a lack of knowledge about statutory remittances (Chakanya, 2016). The working conditions have been found to be hazardous, characterised by occupational fatalities, injuries and illnesses resulting in part, from long working hours, unpaid overtime work, the existence of squalid housing amenities, lack of adequate and appropriate protective clothing (Mukwakwami and Uzhenyu, 2017; Sibanda, 2019). Similar situations have been found at the international level.

Dedeoglu and Bayraktar (2019) found work in agriculture as unattractive, due to low wages, extended working hours, limited worker mobility and tasks that rarely demand any qualifications. The World Employment and Social Outlook (2020) discloses that employees in agricultural jobs, particularly in low-income countries such as Zimbabwe, earn very low wages, suffer from poor working conditions, are lowly skilled and have irregular or no contracts of employment. The ILO (2018) reported that most hazardous work conditions were found in the agricultural industry. William and Horodnic
(2018) established that non-standard forms of work were prevalent in the agriculture industry, particularly the use of temporary employment such as fixed term and casual contracts. In a study of cocoa and tea plantations in the United Kingdom by Lebanon (2018b), it was found out that decent work deficits manifested in the form of labour exploitation, including forced labour; payment of severely low wages; worker abuse and violence in physical, verbal and sexual forms; threats of dismissal, lack of adequate housing, medical care and sanitation; and non or under-payment of incomes. Similarly, the IFC (2016) reported that workplaces in the agribusiness presented several serious hazards to workers, including inadequate access to training, sexual harassment and insecure working environments.

The intensity of the decent work deficits in agriculture required attention, within specific context as averred by Sinaga (2018). Through collective action at the enterprise level, the deficits can be eradicated (Karatepe and Scherrer, 2019). Our research argues that the works council provides a vital social dialogue platform for addressing decent work deficits within the enterprise. It fosters employee participation and can be used by employees to influence management decisions on matters relating to employment relations. The works council offers a platform for management representatives and workers committee members to share vital information, consult and jointly make key decisions concerning work and employment. BelayethHussain and Endut (2018) share that works councils can produce positive outcomes for dealing with unfair treatment at the workplace, while promoting the security and stability of the enterprise. Sibanda (2019) concluded that there was a lack of sufficient information on the social dialogue avenues dealing with decent work deficits in Zimbabwe. The works council provides an avenue through which social dialogue partners at the enterprise level can collaborate and address decent work deficits (ILO, 2019).

This study explores the works council's response to decent work deficits facing agricultural employees through examining its role, and challenges faced, using a selected agrobusiness entity in Zimbabwe. Three questions address this study: 
1. In what ways are decent work deficits manifesting in the organisation?

2. How is the works council addressing the decent work deficits?

3. What challenges militate the works council resolve to tackle the decent work deficits?

\section{MATERIALS AND METHODS}

The research followed a qualitative case approach using a large agrarian organisation in Zimbabwe. The researchers were granted permission to conduct the study, having clarified and explained the purpose and aims for the study. Data were collected from 18 purposively selected participants, all involved in works council business within the organisation. These were made up of 7 management committee members, 9 workers' committee members and 2 representatives of the human resources and industrial relations department. Preference for smaller sample sizes in qualitative research is common, in order to allow for the in-depth examination of a phenomenon (Bryman, 2012). Nine face-to-face interviews were conducted with all management representatives with members of the workers committee taking part in a focus group discussion. Data is analysed thematically.

\section{RESULTS AND DISCUSSION}

\section{Working conditions leading to decent work deficits}

Decent work deficits manifest themselves in the conditions of work. Data provided on Table 1 below summarises the working conditions found to be spreading decent work deficits in the organisation under study.

Table 1: Working conditions extending decent work deficits in the organisation

$>$ Inadequate salaries, resulting in failure to meet basic needs for employees and their families.

$>$ Insufficient provision of personal protective clothing endangering employee health and safety.

> Long hours of work, often unpaid and sometimes not compensated.

$>$ Threats of contract termination from work supervisors.
> Dismissals of employees without disciplinary hearings.

$>$ Employment of under age children without compensation.

> Harassment of employees including sexual demands from female labourers by supervisors.

$>$ Lack of a medical aid facility for employees.

$>$ Inhabitable housing conditions with poor sanitary facilities.

$>$ Most employees are on temporary term contracts and do not benefit from incentives offered.

$>$ Lack of understanding on statutory deductions relating to pension and other taxes.

\section{Field data}

Members of the workers committee shared that working conditions in the organisation were generally poor. Several participants expressed:

Considering that prices for basic commodities are increasing each month, the minimum wages, agreed upon this February 2020 at the National Employment Council (NEC) for the industry cannot sustain employees and their families. The bargaining agreement set minimum wages of ZW\$ 675-00 for the least graded employee, and ZW\$ 1, 339-00 for the highest graded employee. This translates to about US\$16 and US34 respectively. These amounts are barely sufficient to meet basic needs such as school fees, hospital bills, groceries, transport and other necessities, said one participant.

Jobs for many employees in the farm involve use of chemicals and heavy machinery. For a long time, obtaining protective clothing has been a challenge. Many employees use second hand protective clothing and safety shoes bought from either retired staff or informal traders using their own funds. Particularly for casual or temporary staff, this situation is worrying, stated a participant working in a vastly hazardous setting.

We cannot talk of the security of jobs when many of the employees are on contracts which are temporary. Even for those in permanent contracts face poor conditions in this industry. We work for very long hours sometimes 12 to 14 hours in a day, against a standard of nine and a half hours as set in the CBA for the industry. We have no issue with this, except we are not paid for overtime and sometimes denied time-off. Anyone who complains is either dismissed or harassed. The work conditions of work are demoralising, retorted one committee member. 
Many concerns were raised by the workers committee highlighting the precarious nature of jobs in the organisation and the industry at large. Use of young children was identified to be a serious matter of concern, with one participant stating:

Children as young as 14 years are found doing work, disguised as voluntary and are barely paid or sometimes given a little token of appreciation. Many of the parents or guardians to these kids are left without an option except to let the children accept the 'job' offers in return for the little amounts which sometimes augments income levels for the households, reiterated a participant.

Management participants detailed that they were conscious to the predicament of employees with one line manager stating:

The issue of the working conditions has often been raised at both company and industry level. It is an ongoing subject of discussion. Mostly, jobs in this industry are seasonal due to the nature of the industry. Hiring employees on temporary contracts, mostly casual, seasonal and fixedterm is unavoidable. Low productivity facing many agribusinesses remains the greatest challenge. As a result, capacitation to offer and improve working conditions of desirable state is difficult.

Another manager raised:

It is true that employment conditions in this industry are not favourable for, however efforts are continuously being made to improve and ensure decent conditions. Employees are found working long hours, wages are insufficient just as it is reflecting for most industries in the country, and accommodation facilities are not the best at present.

The representatives from the human resources and industrial relations department voiced that working conditions have not been decent, however were of top importance in deliberations at both company and industry level. They maintained that the organisation does not employ anyone below 18 years, except for learning and training basis. While acknowledging that child labour was dominant in the agricultural industry, guidelines aimed at promoting compliance of all employers in the industry existed. One of these two participants shared:

The findings reveal the existence of decent work deficits within the agro-based organisation manifesting through low wages, extensive use of temporary contracts that lack security, long working hours, inhabitable housing conditions, poor occupational health and safety measures and harassment of employees and their representatives. The low wages paid to workers in the organisation and industry inadequately uplift the standards of living for the employees and their families, a key tenet for achieving decent work as reported in the ILO (2012). The existence of occupational hazards associated with a lack of protective clothing, including working long and uncompensated hours is exploitative and abusive conditions as confirmed in the literature (see Chambati, 2017; Mukwakwami and Uzhenyu, 2017). According to the ILO (2012), failure to provide decent working time, safe work environment and work that offers an opportunity for employees to balance work and family life amounts to decent work deficits. The prevalence of indecent working conditions facing employees in the agricultural industry is reported by the World Employment and Social Outlook (2020). These conditions, argues Kalleberg (2018), lead to employment that is uncertain and insecure and goes against the foundational aspirations of the decent work concept, primarily that of advancing fair labour standards as pointed out by Karatepe and Scherrer (2019).

Acknowledging that the agricultural industry by its very nature is seasonal, the investigation found out that usage of temporary contracts had become the norm in the organisation. While a trend in the rise of nonstandard employment, particularly temporary contracts is observed globally (William and Horodnic, 2018), the intense precarity facing agro-employees is rather worrisome. For example, temporary employees are susceptible to immediate termination of employment, including unprocedural dismissals. While Keune and Pedaci (2019) concluded that decent work deficits are more prevalent to employees on non-standard work, this study is of the finding that precariousness has also become a prominent feature for employees on full-time permanent employment.

\section{The role of the works council in addressing decent work deficits}

At the enterprise level, works councils are viewed as significant institutions that can facilitate decent working conditions for employees. 
Various opinions were shared by the 9 workers committee members. Mostly, the participants expressed that works council meetings rarely sat and with each sitting, promises were always made in respect of addressing working conditions to ensure they were decent for the agrarian workers in the organisation. One of the participants stated:

While works council meetings are important and can help make agreements about the conditions of work, we rarely sit, mostly two or three times in a year. When employees raise concerns about conditions of work within their departments, supervisors and managers constantly remind them that the works council was the appropriate forum for addressing concerns of such a nature. This is a clear sign that management does not intend to commit to improving the work situation for the workers.

One other representative shared:

Whenever works council meetings are held and matters of wages and work conditions are raised, management representatives are quick to state that it was not important to continuously raise the same concerns with each meeting as the employer was ceased with addressing these. We have resorted to keeping quiet for fear of victimisation and threats on our contracts as some of us are on fixed-term arrangements.

There was a concurrence by the participants during the focus group discussion that the works council in the organisation was ineffective. They understood that this platform could be used by the employer to communicate management efforts to address working conditions and also jointly establish, with the workers committee, initiatives and coping strategies that could help mitigate the precarious situation for the workers. The participants said while it is agreed that the agriculture industry in general is not well paying and jobs mostly demand low skills, it was not in doubt that working conditions for agrarian employees were poor, making them one of the most vulnerable employees in the Zimbabwean labourforce. They found that lack of knowledge and appropriate skills disadvantaged their participation in meetings at the works council and wished the employer could assist them with relevant training.

As a way of coping with the challenging situation, the workers committee participants stated that the majority of employees resorted to entrepreneurial activities such as selling wares and vegetables to circumvent poverty. With no employment benefits assured for many of the staff in the organisation, some employees are engaged in informal trading. Romantic relationships are also observed as some seek to keep their jobs safe and get contracts renewed. Such issues could be articulated within the works council, as participants shared, expressing that company time is wasted and employee productivity is diminished when employees fail to perform well at work. A participant raised that in the last 2 works council meetings held, management used threats to disband the workers committee accusing members of failing to rein in problematic employees seen as inciting others to challenge management decisions.

A line manager had this to say:

Works councils are important in addressing matters affecting both employees and the company, including issues on working conditions. In this organisation, the works council is less effective due to the limited knowledge and capabilities of the representatives to engage in constructive discussions with management. Efforts to capacitate particularly members of the workers committee are regularly facilitated by our human resources and industrial relations office. Claims that we intimidate employee representatives are unfounded.

Representing the human resources and industrial relations department, one participant stated:

By and large, the works council plays an important role in addressing employment conditions that lead to decent work for employees at a company level. In this establishment, the works council meetings although not regularly held, have been insightful, informing management action in improving the employment conditions. The major challenge would be the weakened economic situation in the country, affecting our operations and obligatory duties.

The other participant from the same department reiterated:

Time and again, incentives, at the discretion of management, have been offered to all our employees so that they can meet basic needs. We are not getting much revenue in light of persistent drought and funding challenges. However, where possible we cater for the welfare of our employees through 
cash or bonus incentives, groceries as well as assistance in paying fees for their children. Through the works council, members of the workers committee are enlightened of the challenges facing the organisation and encouraged to share information with all employees. With more vibrancy, the works council can be used as a platform for both management and employee representatives to continuously engage, share information and conclude meaningful agreements that can be implemented within defined possibilities. Our attempts to have regular interactions via the works council are hindered by challenges which the HR department is working on addressing. Achieving decent work in the organisation and the industry is at the top of the list, for only then can employees productively contribute to the company bottom-line.

The research study explored the role of the works council in addressing decent work deficits in the organisation. Findings established that the works council in the agro-organisation was generally debilitated, playing a negligible role in tackling decent work deficits. When works council structures are weak, typically the tendency is for management to make unilateral decisions and avoid consulting employees as asserted by Ribeiro (2016). Ineffective works council interactions can deprive employees the opportunity to engage in social dialogue and influence management decisionmaking processes. The works council plays a significant role in advancing social dialogue at the enterprise level, yet as opined by Sibanda (2019), less is known about such dialogue institutions in addressing decent work deficits. In the organisation under study, works council meetings are rarely held, and if sat for, management solely sets the agenda and uses it mostly for relaying information rather than making deliberations. This is against one of the foundational dimensions for decent work, namely social dialogue, whose aim is to promote employee participation and ensure labour influences the decision-making processes in the workplace.

There was concurrence by all participants that the works council provides an ideal channel for both management and employee representatives to share, exchange information and make concrete resolutions that can help address decent work deficits. In concurrence, Skorupinska (2018) posits that a works council is an important conduit for promoting the participation by employees in decision-making at work, a view shared by Cam (2019) who avers that works councils can result in effective resolutions. Commitment by managers to genuinely engage in social dialogue was said to be lacking, with constant threats against employee representatives. This is symbolic of unequal power relations in employment relations as noted by De Bruyn and Sotshononda (2017), consequently leading to a failure to tackle decent work deficits.

Management participants pointed the need for works council arrangements to be remodelled to help achieve positive outcomes, including equipping the employee representatives with requisite skills to improve their participation. As concluded by Lopez-Andreu (2019), without essential expertise social dialogue institutions, including the works council will fail. If well-organised and appropriately resourced, works councils can allow for effective employee representation and the conclusion of sound decisions in the workplace (World Employment and Social Outlook, 2020). Skills enhancement is central for parties involved in dialogue, as it improves their confidence to engage with each other constructively, resulting in sound decisions. Tackling decent work deficits becomes a possibility under such a climate.

\section{Works council challenges in addressing decent work deficits}

The study participants identified several challenges as impeding the functioning of the works council, and subsequently presenting problems to addressing decent work deficits within the enterprise. This is despite acknowledgement by all the participants that the works council is a vital institution that can help promote fair labour standards and improve both the quality and conditions of work at the enterprise level.

The workers committee representatives identified leadership as the key problem, stating that management did not believe employees had a role to play in making decisions concerning both work and work organisation in the enterprise. One participant had this to say:

Unless managers begin to value us as representatives of employees, it will not be easy for us to express employee concerns. Many times, we are threatened and reminded 
that we are also ordinary employees and accused of inciting other employees to raise unfounded concerns about working conditions.

Another shared:

We rarely sit for works council meetings, and whenever we do, we are merely informed on decisions taken by management which we are expected to convey to the rest of the staff. When we raise issues on work conditions, they tell us that there is no need to keep reminding them of what they know. We cannot ask them for the feedback until they say it out at their own time, otherwise one may become a victim.

One had to say:

Works council meetings are not that useful here, we do not meet often, the agenda is set by management and threats are used in the meeting on any one who is considered to be challenging decisions by management.

Asked on how they view their preparedness to engage management outside the works council meetings in order to raise their concerns, the participants expressed that while the HR office was in place, promises were constantly being made to address their concerns without success. They believed that the HR office could help them with acquiring knowledge that would help them to effectively represent employee concerns. The participants revealed that among all the workers committee members only three had post-secondary level qualifications while the rest did not have any educational qualifications. They perceived this to be hindering participation in decision-making. The temporary nature of employment contracts for most of employees in the enterprise and continued threats of dismissal had resulted in some form of adaptation to the indecent work situations. Asked on the possibility to engage in legal collective job action in order to address working conditions that aggravated decent work deficits, the participants highlighted that such considerations would undoubtedly lead into immediate dismissal, and in view of the current economic challenges fronting the nation, no worker would risk becoming jobless. The hope of the workers committee was that management and particularly the human resource and employment relations department would assist them with necessary training that will help improve participation in decisionmaking.

Management participants shared that while works council meetings provided a springboard for sharing and exchanging vital information with employees, meetings were irregularly held, citing coordination challenges as many of the management representatives constantly rotated across the different plantations on a daily basis. Two-line managers shared that the workers committee members in many occasions did not speak during the works council meetings justifying management domination. However, one management participant refuted claims of victimisation citing lack of knowledge and confidence as the contributory factors to limited participation by the workers committee during works council meetings. A participant from the human resources and employment relations department voiced:

Our office is working towards skilling members of the workers committee with an aim to improve their participation in works councils. We believe that they can represent employee concerns including those relating to decent work deficits that your study is founded on. As we stand, works council meetings are rarely held, in part due to issues relating with organising the geographically dispersed members, and also in view that we need to build confidence among all representatives. That way the level of interaction would improve, and consequently result in fruitful outcomes particularly in respect of promoting decent work situations.

Findings reveal the challenging economic situation prevailing in the country as a major cause for failing to adequately address the poor working conditions in the company. Management shared that persistent drought and poor funding led to depressed revenue in the organisation, and the industry as a whole, frustrating efforts to address employee concerns. Zimstat (2019) confirms that productivity and performance in Zimbabwe's agricultural industry is fraught with several challenges including a lack of agricultural inputs and finance, recurrent droughts, high costs for purchasing inputs, poor management and low funding. Given such challenges, the capacity for organisations or works councils to address decent work deficits is limited. Nonetheless, participants concurred on 
the need for the human resources and employment relations department to facilitate trainings that would equip employee representatives with appropriate skills and knowledge for effective participation in the works councils. Similarly, the International Finance Corporation (2016) discloses the important role that practitioners in the human resource management can play in the design of appropriate training programs that will equip employer and employee representatives with substantial skills and competences for enhancing the functioning of works councils.

\section{RECOMMENDATIONS AND CONCLUSION}

The study recommends the following actions be undertaken in the organisation in order to ensure the efficient functioning of the works council, and enable the effective redress of the decent work deficits experienced by employees:

* There is a need for the human resource management function to actively advocate for regular works council meetings, and enlighten management on the impacts of a failure to address decent work deficits in the organisation.

* In setting the agenda for the works council meetings, consultation must be made with both management and workers committee members prior to any such meetings.

* Regular training of works council participants is vital to improving their participation and instilling confidence, trust and effective interactions, leading to sound decisions.

* The human resources and employment relations department can facilitate workshops, on a regular basis, aimed at equipping all management with leadership competences and foster leadership behaviours that are people-orientated. This can lead to management actions that are predicated on the promotion of fair labour standards, and promptness in detecting and addressing decent work deficits in the organisation.

In conclusion, the study confirms the pervasiveness of decent work deficits in agribusiness. A common viewpoint in the literature is that decent work deficits manifest in the conditions of work. Through this study, several indicators to the existence of the deficits in the organisation were found. These included, inter alia, measly wages that were barely sufficient to meet one's basic standards of living; long working hours; use of temporary employment forms with little security of tenure; insufficient or failure to provide personal protective gear, endangering the safety and health of employees; harassment and threats of dismissal of employees; and lack of employment security. The works council in the organisation was found to be ineffective in addressing existing decent work deficits due to poor coordination and irregular convening of works council meetings. In addition, the domineering management approach through the use of threats against workers committee members, coupled with the existence of deficient skills and negotiation competencies deterred the effective participation by employee representatives in works council interactions.

Decent work deficits remain a major concern in the world of work. Evidence points towards the intensification of the deficits within enterprises in the agricultural industry. To optimise productivity and performance of employees, management practitioners and human resource management professionals need to be conscious to employee issues and actively promote fair labour standards in the workplace. At the enterprise level, the works council can be used as a social dialogue institution for addressing decent work deficits.

\section{REFERENCES}

Akorsu, D.A. and Britwum, O.A. 2018. Trade Union's Response to Decent Work Deficit among Agricultural Workers in Ghana. In C. Scherrer \& S. Verma (Eds.), Labor and Globalization volume 11. Decent Work Deficits in Southern Agriculture: Measurements, Drivers and Strategies. (pp. 251-272). München: Rainer Hampp Verlag, Augsburg.

Belayeth-Hussain, A.H.M. and Endut, N. 2018. “Do decent working conditions contribute to work-life balance: A study of small enterprises in Bangladesh". Asia Pacific Journal of Innovation and Entrepreneurship, 12(1): 90-104.

Bryman, A. 2012. Social Research Methods. New York, Oxford University Press.

Cam, E. 2019. Social Dialogue and Democracy in the workplace: Trade Union and Employer Perspective from Turkey. Ankara: Springer. 
Chakanya, N. 2016. Minimum Wages and Collective Bargaining in Zimbabwe. Africa Labour, Research and Education Institute and Wage Indicator Foundation, Lome. Retrieved from https:// www.alrei.org

Chambati, W. 2017. Changing Forms of Wage Labour in Zimbabwe's New Agrarian Structure. Agrarian South: Journal of Political Economy, 6(1): 79-112.

Dedeoglu, S. and Bayraktar, S.S. 2019. Refuged into Precarious Jobs: Syrians' Agricultural Work and Labor in Turkey. In G. Yilmaz, D-I. Karatepe \& T. Toren (Eds.), Labor and Globalization volume 17. Integrations through Exploitation: Syrians in Turkey. (pp. 13-27): München: Rainer Hampp Verlag, Augsburg.

De Bruyn, A.J. and Sotshononda, N. 2017. Harnessing Dispute Resolution in a Metropolitan Bargaining Council of South Africa. African Journal of Public Affairs, 9(8): 135-150.

Hyman, R. and Grumbell-McCormick, R. 2017. Resisting labour market insecurity: Old and new jobs, rivals or allies? Journal of Industrial Relations, 59(4): 538-561.

International Finance Corporation. 2016. The Business case for Women's Employment in Agribusiness. IFC Communications, Washington Retrieved from http://www.ifc.org/gender/

International Labour Organisation. 2019. Work for a brighter future. Global Commission on the future of work. ILO: Geneva.

International Labour Organisation.2018. Back to the Future: Challenges and Opportunities for the future of work addressed in ILO Sectoral meetings since 2010. Paper No. 317, Sectoral Policies Department, ILO: Geneva.

International Labour Organisation. 2012. Decent Work Indicators in Africa: a first assessment based on national sources. Geneva: ILO. Retrieved from

https://www.ilo.org/sta/Publications/WCMS_189222/

International Monetary Fund. 2019. Zimbabwe Staff-monitored program-Press Release and Staff Report. IMF Publication Services: Washington DC.

Kalleberg, A.L. 2018. Job insecurity and well-being in Rich democracies-Geary-Lecture 2018. The Economic and Social Review, 49(3): 241-258.

Karatepe, D.I. and Scherrer, C. 2019. Collective Action as a Prerequisite for Economic and Social Upgrading in Agricultural Production Networks. Agrarian South: Journal of Political Economy, 8(1-2): 115-135.

Keune, M. and Pedaci, M. 2019. Trade union strategies against precarious work: Common trends and sectoral divergence in the European Union. European Journal of Industrial Relations. Retrieved from https://doi.org/10.1177/0959680119863585
LeBaron, G. 2018. The Coming and Current Crisis of Indecent Work. In C. Hay \& T. Hunt (Eds.), The Coming Crisis. Building a Sustainable Political Economy: SPERI Research Policy (pp. 43-56). Cham: Palgrave MacMillan.

Lopez-Andreu, M. 2019. Neoliberal trends in collective bargaining and employment regulation in Spain, Italy and the UK: From institutional forms to institutional outcomes. European Journal of Industrial Relations, 25(4): 309-325.

Mukwakwami, H. and Uzhenyu, D. 2017. Rife of Casualisation of Labor in Zimbabwe's Agricultural Sector: A Retrogressive Practice to Employment Security. Journal of Business and Management, 19(9): 72-77.

Ribeiro, A. T. 2016. Trends in Collective Bargaining in Europe. E-Journal of International and Comparative Labour Studies, 5(1): $1-23$.

Scherrer, C. 2019. Foreword. In G. Yilmaz, D-I. Karatepe \& T. Toren, (Eds.), Labor and Globalization volume 17. Integrations through Exploitation: Syrians in Turkey. (pp. xi-xii). München: Rainer Hampp Verlag, Augsburg.

Sibanda, S. 2019. Promoting decent work in the rural economy: Lessons from Zimbabwe (2008-2018). Harare: International Labour Office.

Sinaga, H. 2018. Measuring Decent Work Deficits on Indonesian Oil Palm Plantations. In C. Scherrer \& S. Verma (Eds.), Labor and Globalization volume 11. Decent Work Deficits in Southern Agriculture: Measurements, Drivers and Strategies. (pp. 13-33). München: Rainer Hampp Verlag, Augsburg.

Skorupinska, K. 2018. The failure of a new form of employee representation: Polish works councils in comparative perspective. European Journal of Industrial Relations, 24(2): 163178.

Verma, S. 2018. Liberalising the Seeds and Pesticides Markets in India. In C. Scherrer \& S. Verma (Eds.), Labor and Globalization volume 11. Decent Work Deficits in Southern Agriculture: Measurements, Drivers and Strategies. (pp. 13-33). München: Rainer Hampp Verlag, Augsburg.

William, C.C. and Horodnic, A. 2018. Tackling Undeclared Work in the Agriculture Sector. 2017-2018 Work programme of the European Platform tackling undeclared work. Retrieved from http://ec.eropa.eu/social/easi/

World Employment Social Outlook. 2020. Trends for 2020. Document \& Publications Production, Printing and Distribution Branch, Geneva: International Labour Organisation.

Zimstat. 2019. Zimbabwe Smallholder Agricultural Productivity Survey 2017 Report. Harare: Zimbabwe National Statistical Agency, Causeway. 
